\title{
Is an increased body mass index associated with a risk of cutaneous leishmaniasis?
}

\author{
0 índice de massa corporal aumentado é associado \\ a risco de leishmaniose cutânea?
}

\author{
Daniel Ferreira da Cunha ${ }^{1}$, Selma Freire de Carvalho da Cunha ${ }^{1}$, \\ Adriana Guimarães Nunes ${ }^{1}$ and Mário León Silva-Vergara ${ }^{1}$
}

\begin{abstract}
All adults $(\mathrm{n}=334)$ living in Brejo do Mutambal, an endemic area for cutaneous leishmaniasis, were included in this study. Contrary to our initial hypothesis, it was observed that men $\left(23.7 \pm 3.2\right.$ vs. $\left.22.1 \pm 2.6 \mathrm{~kg} / \mathrm{m}^{2}\right)$ and women $\left(24.1 \pm 4.7 \mathrm{vs.} 22.5 \pm 3.4 \mathrm{~kg} / \mathrm{m}^{2}\right)$ with cutaneous leishmaniasis presented higher body mass index than the controls.
\end{abstract}

Key-words: Cutaneous leishmaniasis. Nutritional status. Overweight. Obesity.

\section{RESUMO}

Neste estudo, foram incluídos todos $\left(n^{\circ}=334\right)$ os adultos morando em Brejo do Mutambal, região endêmica para leishmaniose cutânea. Contrário à hipótese inicial, observou-se que homens $\left(23,7 \pm 3,2\right.$ vs. $\left.22,1 \pm 2,6 \mathrm{~kg} / \mathrm{m}^{2}\right)$ e mulheres $(24,1 \pm 4,7 \mathrm{vs.} 22,5 \pm 3,4 \mathrm{~kg} / \mathrm{m} 2)$ com leishmaniose cutânea apresentaram maior índice de massa corporal que os controles.

Palavras-chaves: Leishmaniose cutânea. Estado nutricional. Sobrepeso. Obesidade.

Malnourished children are at increased risk of parasitic infections, including visceral ${ }^{2}$ and cutaneous leishmaniasis ${ }^{9}$. Furthermore, immune activation of parasitized macrophages in the mononuclear phagocyte system is associated with severe malnutrition, characterized by anemia, hypoalbuminemia and fat and muscle wasting ${ }^{1249}$. In addition, children with recurrent or chronic infections of the dermis or the respiratory or gastrointestinal tracts may exhibit somatic growth failure, which is thought to be caused by subclinical, low-level stimulation of their immune system, with the catabolic consequences of the acute-phase response ${ }^{12}$.

Although some studies have already described the nutritional status of children with Leishmania infection ${ }^{1212}$, no reference was found in the literature regarding the nutritional status of adults with cutaneous leishmaniasis (CL). Since body mass index (BMI, weight divided by the square of the height) has been used to describe the nutritional status of adults in clinical and epidemiological studies $^{5}$, the aim of this study was to investigate whether adults with CL would have lower body mass index than a control group of individuals without CL.

1. Departament of Clinical Medicine, Federal University of Triangulo Mineiro, Uberaba, MG, Brazil.

Financial support: Fapemig, CNPq, Research foundation of Uberaba (FUNEPU)

Address to: Prof. Daniel Ferreira da Cunha. Discipline of Nutrology, Departament of Clinical Medicine/UFTM. Av. Getúlio Guaritá 130, 38025-440 Uberaba, MG, Brazil.

Telefax: $55343318-5335$

e-mail: dfnutro@gmail.com

Received in 09/12/2008

Accepted in 21/08/2009

\section{SUBJECTS AND METHODS}

This cross-sectional study was carried out in a village called Brejo do Mutambal, which is located in the semiarid rural zone of the municipality of Varzelândia, in the northeast of the state of Minas Gerais, Brazil, an endemic area for cutaneous and mucosal leishmaniasis. The village is closely surrounded by rocky hills of about 10-12 meters high, and has about 700 inhabitants living in adobe houses, with electricity but only rarely with adequate sanitation and water supply. The Research Ethics Committee of the Medical School of the Triângulo Mineiro University, Uberaba, Brazil, approved the study. Informed consent was obtained from all participants.

All adults (age $\geq 18$ years; $n=334$ ) living in the village were included. Anthropometry was carried out, consisting of height measurements, without shoes, to the nearest $0.1 \mathrm{~cm}$ using a nonextensible tape, and weight measurements while wearing light clothes and without shoes, to the nearest $0.1 \mathrm{~kg}$ using portable scales. Body mass index (BMI) was defined as the weight in kilograms divided by the square of the height in meters $\left(\mathrm{kg} / \mathrm{m}^{2}\right)$, and the following criteria were used': underweight $\left(\mathrm{BMI}<18.5 \mathrm{~kg} / \mathrm{m}^{2}\right)$, normal (BMI within the range of $18.5-25 \mathrm{~kg} / \mathrm{m}^{2}$ ), and overweight/ obese $\left(\mathrm{BMI}>25 \mathrm{~kg} / \mathrm{m}^{2}\right)$. Cutaneous leishmaniasis (CL) was defined by the presence of an active ( $<5 \%$ of cases) or healed, atrophic and depigmented ulcer diagnosed by a dermatologist, plus a positive Montenegro test. The latter is a delayed cutaneous hypersensitivity test with sensitivity of 86 to $100 \%$, and specificity of $100 \%{ }^{6}$. All numerical variables were expressed as 
mean \pm standard deviation. Differences between the CL and control groups were compared by means of the non-paired "t" test. Chi-square or Fisher's exact tests were performed to compare frequencies. Probabilities less than 0.05 were considered significant.

\section{RESULTS}

Cutaneous leishmaniasis was diagnosed in 86 (25.7\%) cases: $54.7 \%$ (47) in men and $45.3 \%$ (39) in women. There was predominance $(71 \%)$ of nonwhite individuals (black, brown or mulatto skin color), without any statistical difference between the CL and control groups. Age, height, weight and BMI, along with percentage malnutrition and overweight and obesity among the CL and control groups are shown in the Table 1. Overweight/ obesity occurred in 38 cases ( $11.4 \%$ of the total), with higher frequency among women than among men (15 vs. $7.8 \%$; $\left.\chi^{2}=4.28, \mathrm{p}<0.05\right)$. Among women, obesity was more common in CL cases than in controls ( 25.6 vs. $11.7 \%, \chi^{2}=4.55, \mathrm{p}<0.05$ ); the odds ratio for CL among obese women was 2.60 (95\% confidence interval, 0.96-6.95). Overweight/obesity was also statistically more common among men with cutaneous leishmaniasis (14.9 vs. $5 \%$ ); the odds ratio for CL among overweight/obese men was 3.33, with 95\% confidence interval of 0.93-12.02.

\section{TABLE 1}

Age, height, weight, body mass index (BMI) and frequency of overweight/obesity or underweight among 334 men and women living in an endemic area of cutaneous leishmaniasis (village of Brejo do Mutambal, Minas Gerais, Brazil).

\begin{tabular}{lccccc}
\hline & \multicolumn{2}{c}{ Men $(\mathrm{n}=167)$} & & \multicolumn{2}{c}{ Women $(\mathrm{n}=167)$} \\
\cline { 2 - 3 } \cline { 6 - 7 } & $\mathrm{CL}$ & Controls & & $\mathrm{CL}$ & Controls \\
& $(\mathrm{n}=47)$ & $(\mathrm{n}=120)$ & & $(\mathrm{n}=39)$ & $(\mathrm{n}=128)$ \\
\hline Age (years) & $42.2 \pm 15.9$ & $41.5 \pm 20.0$ & & $47.3 \pm 17.0$ & $45.0 \pm 17.2$ \\
Height $(\mathrm{cm})$ & 168.30 .07 & $168.4 \pm 0.07$ & & $156.0 \pm 0.06$ & $154.3 \pm 0.06$ \\
Weight $(\mathrm{kg})$ & $67.210 .3^{*}$ & $62.6 \pm 8.8$ & & $58.9 \pm 13.0^{*}$ & $53.6 \pm 8.6$ \\
BMI $\left(\mathrm{kg} / \mathrm{m}^{2}\right)$ & $23.7 \pm 3.2^{*}$ & $22.1 \pm 2.6$ & & $24.1 \pm 4.7^{*}$ & $22.5 \pm 3.4$ \\
Underweight $(\%)$ & 4.2 & 5.8 & & 10.2 & 11.7 \\
Overweight/obesity $(\%)$ & $14.9^{*}$ & 5.0 & & $25.6^{*}$ & 11.7 \\
\hline
\end{tabular}

*Cutaneous leishmaniasis (CL) cases differed from controls $(\mathrm{p}<0.05)$.

\section{DISCUSSION}

The causes of these frequencies of BMI and overweight/obesity among individuals with CL are unclear. Regular topographical conditions such as the rocky hills surrounding the village of Brejo do Mutambal, and high and similar frequencies of CL among men and women suggest that peridomestic transmission of the Leishmania infection was occurring. In this setting, greater exposure of overweight/obese individuals to sandfly bites is not an acceptable explanation. Rather, a preference among sandflies for biting weightier or obese individuals, as seen with exposure to malarial mosquitoes during pregnancy ${ }^{8}$, is a plausible hypothesis that should be tested by further investigation. Obese individuals often have high serum leptin levels, with or without insulin resistance ${ }^{10}$. Since leptin also regulates the balance of $\mathrm{T}$ helper cytokines (Th1/Th2), and the production of several pro and antiinflammatory cytokines ${ }^{3}$, further studies investigating possible interactions between leptin and cytokines should be conducted among obese patients with cutaneous leishmaniasis.

The limitations of this study include lack of information about current host food intake and immune response details to Leishmania infection, as well as lack of information about the activity of the disease at the time of this study. Nonetheless, because undernutrition and overnutrition are the two endpoints of the malnutrition spectrum, these obese individuals may have had impaired immunity associated with the consumption of imbalanced diets 7 . Moreover, because spontaneous healing of cutaneous ulcers may occur in healthier individuals, it cannot be ruled out that obese individuals with better general health may have presented a better immune response ${ }^{7}$. In addition to studies confirming our findings in other regions, the present study also demands clinical and laboratory research, including in relation to the Th1 and Th2 responses of obese individuals challenged with Leishmania species.

\section{ACKNOWLEDMENTS}

To FAPEMIG, CNPq, and the Teaching and Research Foundation of Uberaba (FUNEPU).

\section{REFERENCES}

1. Cunha DF, Lara VC, Monteiro JP, Romero HD, Cunha SFC. Retardo do crescimento em crianças com reação intradérmica positiva para leishmaniose: resultados preliminares. Revista da Sociedade Brasileira de Medicina Tropical 34: 25-27, 2001.

2. Dye C, Williams BG. Malnutrition, age and the risk of parasitic disease: visceral leishmaniasis revisited. Proceedings of the Royal Society of London: Series B, Biological Sciences 254:33-39, 1993.

3. Faggioni R, Feingold KR, Grunfeld C. Leptin regulation of the immune response and the immunodeficiency of malnutrition. The FASEB Journal 15: 2565-2571, 2001.

4. Herwaldt BL. Leishmaniasis. The Lancet 354:1191-1199, 1999.

5. Heymsfield SB, Tighe A, Wang ZM. Nutritional assessment by anthropometric and biochemical methods. In: Shils ME, Olson JA, Shike M (eds) Modern Nutrition in Health and Disease, $8^{\text {th }}$ edition, Lea \& Febiger, Malvern, p. 812-841, 1994.

6. José FF, Silva, IM, Araújo MI, Almeida RP, Bacellar O, Carvalho EM. Avaliação do poder sensibilizante da reação de Montenegro. Revista da Sociedade Brasileira de Medicina Tropical 34:537-542, 2001.

7. Kumari BS, Chandra RK. Overnutrition and immune responses. Nutrition Research 13:S3-18, 1993.

8. Lindsay S, Ansell J, Selman C, Cox V, Hamilton K, Walraven G. Effect of pregnancy on exposure to malaria mosquitoes. The Lancet 355:1972, 2000.

9. Pérez H, Malavé I, Arredondo B. The effects of protein malnutrition on the course of Leishmania mexicana infection in C57B1/6 mice: nutrition and susceptibility to leishmaniasis. Clinical and Experimental Immunology 38:453-460, 1979.

10. Santos LC, Cintra IP, Fisberg M, Martini LA. Body trunk fat and insulin resistance in post-pubertal obese adolescents. Sao Paulo Medical Journal 126:82-86, 2008.

11. Solomons NW, Mazariegos M, Brown KH, Klasing K. The underprivileged, developing country child: environmental contamination and growth failure revisited. Nutrition Reviews 51:327-332, 1993.

12 Weigel MM, Armijos RX, Zurita C, Racines J, Reddy A, Mosquera J. Nutritional status and cutaneous leishmaniasis in rural Ecuadorian children. Journal of Tropical Pediatrics 41:22-28, 1995. 